\title{
DEVELOPING A METHOD FOR ANALYZING INSTITUTIONAL CHANGE
}

\author{
by \\ Elinor Ostrom \\ Workshop in Political Theory and Policy Analysis, Indiana University \\ Center for the Study of Institutional Diversity, Arizona State University
}

(C) 2007 by author

Forthcoming 2008 in Assessing the Evolution and Impact of Alternative Institutional Structures, ed. Sandra Batie and Nicholas Mercuro. London: Routledge Press. 


\section{DEVELOPING A METHOD FOR ANALYZING INSTITUTIONAL CHANGE}

\section{Elinor Ostrom}

The stimuli for writing this paper come from multiple sources. First, both Allan Schmid (2004) and Douglass North (2005) have urged social scientists to move beyond the static and mechanistic analysis of much of contemporary political economy and game theory that focuses on a given situation and derives predictions regarding likely outcomes. Our tools, however, are most powerfully developed for the analysis of unchanging worlds. The world, however, is always changing. The next important step for social science is developing a cluster of tools for analyzing dynamic situationsparticularly institutional change. Fortunately, in chapter 13 of Conflict and Cooperation: Institutional and Behavioral Economics, Schmid has initiated a major effort to introduce approaches that can be used in the analysis of institutional change. Among the approaches he identifies is one that examines the three processes of "Social Learning, Evolution, and Emergence.” This paper is an effort to examine these processes in the context of an analysis of irrigation institutions. I focus on the processes of institutional change in relation to irrigations institutions as I do not think we can develop a general theory of institutional change until we understand the processes of change in multiple specific settings. Hopefully, the lessons learned from specific settings can be integrated into a more general theory as we progress to understand specific types of situations.

Thus, a second major stimulus for writing this paper is an effort to develop some more general lessons from the research that many colleagues have undertaken to analyze the structure and performance of irrigation systems—-particularly in Nepal. In our research, we have repeatedly found that resource users, who have relative autonomy to 
design their own rules for governing and managing common-pool resources, frequently achieve better outcomes than when experts do this for them (Ostrom, 1990; Agrawal and Gupta, 2005; Gibson, McKean, and Ostrom, 2000; Blomquist, 1992; Tang, 1992; Ostrom, Gardner, and Walker, 1994; Shivakoti and Ostrom, 2001; Acheson, 2003; Schlager and Ostrom, 1992). In addition to extensive fieldwork and statistical analysis, we have used game theory to illustrate how the rules that resource users have developed generate positive outcomes (Weissing and Ostrom, 1991, 1993; Gardner and Ostrom, 1991; Ostrom, 1995; Acheson and Gardner, 2004) as well as undertaken extensive experimental studies to verify these patterns under controlled conditions (Ostrom, Walker, and Gardner, 1992; Ostrom and Walker, 1991; Ostrom, Gardner, and Walker, 1994). The puzzle is, however, how do resource users do this? As briefly summarized in the next section, we find that farmers, who lack education or formal training, can on average outperform highly educated engineers in the design and operation of irrigation systems. What is the process that produces these outcomes?

Farmers in old and established systems tell researchers that they do not know much about the origin of the rules they use. In some cases, rules are treated as part of a sacred religious system and are monitored and enforced by priests (Lansing, 1991, 2006). Agricultural scientists, engineers, and government officials treated these systems as based only on superstition. In Bali, for example, after the government of Indonesia required higher rice production by farmers, external experts tried to teach the farmers how to manage their irrigation systems in a "modern and more efficient manner." The rice varieties of the green revolution were implemented in order to reach three crops per year (Spiertz, 1991). This change meant that the farmers did not follow their original rhythm 
of rice production. The experts eventually discovered, however, that the age old system was really relatively sophisticated in its manner of averting the spread of pests as well as careful coordination of water delivery itself. In light of disastrous pest outbreaks after some of the farmers changed their earlier practices, the experts have had to reverse their earlier efforts to make the peasants adopt modern management techniques for the irrigation systems (Lansing and Kremer, 1993; Janssen, 2007).

In discussions with farmers who have built and managed more recent systems, one hears about how hard it is to find the right combination of rules that work in a particular setting. They have had to try out multiple combinations of rules and keep making small adjustments to get the system working well and insure that most farmers actually follow the rules that they decide upon. On the basis of past field research, we can assert that when those closely involved in governing and managing a resource do have relative autonomy to devise their own rules, they cannot foresee all the outcomes that a change in rules produce (Hilton, 1990; Shivakoti et al., 1997; Shivakoti, 1992; Ostrom, 1992). They have to learn over time by tinkering with rules so as to cope with diverse biophysical systems including rainfall patterns, soil, geology, as well as with the cultural and economic systems in which they live.

If we are to understand these changes, we must develop new tools (Jones, 2003). Several colleagues and I are in the early stages of a study of the "dynamics of rules" (Anderies, Janssen, and Ostrom, 2004; Janssen and Ostrom, 2006). ${ }^{1}$ We will use agent based modeling as one of our tools since that does enable one to examine the pattern of likely outcomes over time when agents who have limited information are making choices over time (Janssen, 2002). We also intend to study institutional choice overtly, both in the 
experimental laboratory as well as in the field with companion modeling by participants who have experience in working with irrigation, fisheries, and forest resources (Cardenas and Ostrom, 2004; Cardenas, 2000; Cardenas, Stranlund, and Willis, 2000; Bousquet et al., 2002). We have already examined the difference in cooperative behavior when participants in an open-access foraging experiment have a chance to choose rules to regulate their behavior as contrasted to just learning from experience about the structure of the experiment (Janssen et al., 2006).

The remainder of the paper is organized in the following fashion. In the first main section, I provide an overview of our findings from studying irrigation systems in the field so that readers who are not familiar with our prior research gain an initial sense of these findings. In the next section, I provide a second overview—-this time of the Institutional Analysis and Development (IAD) framework that we have been developing at the Workshop since the early 1980s in an effort to provide a general method for doing institutional analysis (Kiser and Ostrom, 1982; Ostrom, Gardner, and Walker, 1994;

Ostrom, 2005). ${ }^{2}$ In the third section, I introduce the possibility of looking at the change of rules as an evolutionary process.

The new method for studying the evolution of rules, which is introduced in the fourth section, will be based on the IAD framework and on our long-term study of rules related to irrigation systems. Before one can really think of developing a general theory of institutional change, it is helpful to begin to understand change in a specific type of setting. The method will focus on a technique for arraying a norm and rule inventory and recording changes in that inventory over time brought about by diverse processes for making changes. In the conclusion, I return to the question as to why it is important to 
authorize resource users' relative autonomy in the development of their own rules and to learn from the resulting institutional diversity. Rule diversity can generate higher outcomes than the institutional monocropping of imposed rules by external experts (Evans, 2004).

\section{Comparing farmer-managed to agency-managed irrigation systems in Nepal}

Farmers have survived over the centuries in much of Asia due to their evolved knowledge of how to engineer complex irrigation systems including dams, tunnels, and water diversion structures of varying size and complexity (Shivakoti et al., 2005). None of these systems work well, however, without agreed upon rules for allocating water as well as allocating responsibilities for providing the needed labor, materials, and money to build the systems in the first place and maintain them over time.

No one really knows how many farmer-managed irrigation systems (FMIS) currently exist in Nepal. The best estimate is that there were around 20,000 such systems ten years ago and that of the total irrigated land in the country, 75 percent was served only by FMIS (APROSC and JMA, 1995). The existence of multiple systems organized in diverse ways has provided an excellent opportunity to compare the performance of systems organized by the farmers themselves as contrasted to systems designed by engineers working for a donor or a national government.

Colleagues associated with the Irrigation Management Systems Study Group at the Institute of Agriculture and Animal Science, Tribhuvan University in Nepal, have been working with colleagues at Indiana University since the early 1990s (Benjamin et al., 1994; Lam, Lee, and Ostrom, 1994). We have jointly developed the Nepal Irrigation Institutions and Systems (NIIS) database that now has information on over 200 irrigation 
systems located in 29 out of the 75 districts in Nepal. ${ }^{3}$ Our consistent finding, and that of other scholars doing research on irrigation in Nepal (Gautam, Agrawal, and Subedi, 1992), is that on average FMIS outperform agency-managed irrigation systems (AMIS) on multiple dimensions.

Let me provide a very brief overview of our findings from the NIIS database. ${ }^{4}$ Focusing on evaluations of the physical condition of the irrigation system at the time of data collection, as shown in Table 1, a larger proportion of FMIS as contrasted to AMIS maintain the overall physical condition of the system in excellent or moderately good condition and achieve higher technical and economic efficiencies (see Lam, 1998 for definitions of these concepts).

(Table 1 about here)

The specific rules that the farmers use in governing their systems on a day-to-day basis vary substantially from one system to another. The "official" guard on many of these systems is one of the farmers themselves who "rotates" into this position on a regular basis. The rules specifying resource allocation, responsibilities for monitoring, and punishment, however, vary substantially from one system to the next. Thus, the monitoring of water allocation and contributions to maintenance is largely performed by farmers who have participated in the crafting of the specific rules of their own system and have a strong interest in seeing their system perform well and insure that others on the system are not free riding or taking more water than their official share.

The study of irrigation systems in Nepal is only one of the empirical studies we have undertaken over the past quarter of a century focusing on institutional arrangements and their impact on incentives, behavior and outcomes. In our effort to build a more 
general theoretical understanding of how institutions interact with the biophysical and cultural worlds in which they structure incentives, we have had to develop a general framework that enables us to use a meta-theoretical language. The framework enables us to compare work conducted in formal game theoretical analyses with research conducted in the experimental lab and with findings from field research. In our effort to begin a serious study of the dynamics of rule systems, we will again build on the framework that has been so important in all of our past research.

\section{The Institutional Analysis and Development (IAD) framework}

Colleagues at the Workshop in Political Theory and Policy Analysis have developed a broad framework — the Institutional Analysis and Development (IAD) framework that is used to analyze both the simple arenas that are amenable to specifying a formal game or an agent-based model for analyzing more complex structure with too many nodes and links to be analyzed formally. ${ }^{5}$

\section{Focusing on action situations}

In order to focus on the structure of any particular focal arena and likely interactions and outcomes, formal theorists have usually assumed that the underlying factors affecting a particular structure are fixed for the purpose of analysis. This makes it feasible to concentrate effort on predicting what would happen within a static game itself. To model a human-interaction as a game, the theorist must decide which components to use from a set of seven working parts of an interaction as well as how the individuals who are interacting will be modeled. As shown in Figure 1, one can think of human interaction situations as composed of participants in positions choosing among actions at particular stages of a decision process in light of their control over a choice node, the information 
they have, the outcomes that are likely, and the benefits and costs they perceive for these outcomes. When analyzed formally these are the working parts of a game.

(Figure 1 about here)

Before predicting likely actions of participants and resulting outcomes, a theorist must make assumptions about the individual participants: the information they have, their preferences, and how they make decisions (maximize own net benefits, or use heuristics, or engage in conditional cooperation). Most game-theoretical analyses rely on a highly simplified theory of human behavior which has proved itself useful in predicting behavior in competitive situations (Alchian, 1950; Satz and Ferejohn, 1994). Explanations of human behavior in social dilemma situations, however, must use a broader theory of boundedly rational, potentially norm-using, individual behavior (Ostrom, 1998; Cox, 2004; Frohlich, Oppenheimer, and Kurki, 2004).

Further, many of these models treat the arena containing a human-interaction situation and the individuals in it as an analytic whole to be dissected without digging into the underlying exogenous variables that are discussed in the next section. When one models a resource appropriation game, for example, specific aspects of it being located in a forest, a fishery, or a lake may not make a difference in the focal game to be analyzed (see Ostrom, Gardner, and Walker, 1994). In other cases, specific aspects of the biophysical world are essential components to be included (Acheson and Gardner, 2004; Ostrom, 1995). In addition, the type of disturbance facing one system may vary dramatically from those facing another similar system (Baker, 2005; Janssen, Anderies, and Ostrom, 2007). If the situation is repeated and individuals learn about the strategies chosen by others and their outcomes, adaptation, imitation, and learning may lead to 
significant changes in outcomes (of the fixed structure) over time (see Axelrod, 1984;

Güth and Kliemt, 1998; Gintis, 2004).

\section{Focusing on the biophysical world, communities, and rules}

Whenever one is interested in understanding processes of structural change of a particular situation itself, however, one has to open up and overtly include one or more of the underlying "exogenous" sets of variables. As shown in Figure 2, underlying all situations are three broad variables: (1) the biophysical world, (2) the broader community of the participants themselves, and (3) the rules-in-use. All of these variables are composed of multiple subparts. Further, all are nested in larger systems that may vary themselves over time.

(Figure 2 about here)

The Biophysical World. When analyzing problems of irrigated agriculture, for example, the rainfall patterns, underlying geologic structure, stream and lake size, soil types, and slope are all important variables affecting a focal arena. The problems of running an irrigation system in a monsoon climate pattern are entirely different than in a semi-arid zone. Irrigation systems along steep slopes face different problems than systems located along a relatively flat domain (Regmi, 2006).

The biophysical world does not, of course, need to be viewed as only an “exogenous” variable. Whenever the research question of interest to scholars relates to changes in the biophysical world, this variable moves from being exogenous to being a part of the analysis. Research on the resilience of social-ecological systems focuses precisely on fast and slow moving biophysical variables as they affect human interactions and changes in strategies (Anderies, Janssen, and Ostrom, 2004; Berkes, Colding, and 
Folke, 2003; Hughes et al., 2005). Further, technology affects how a biophysical world operates over time, and changes in technology may have substantial impact on the incentives facing individual participants.

Attributes of Community. Many variables can be used to analyze relevant attributes of a community that are likely to affect behavior in human interaction situations (Richerson and Boyd, 2005). Whether farmers, who are trying to manage an irrigation system, live in a small, stable community or a large, ever-changing area does make a substantial difference in regard to the presence or absence of shared norms that facilitate coping with such difficult processes. Many studies of self-organizing resource regimes have found that when a local community is relatively homogeneous and stable (e.g. the rate of change in the composition and size of the community is low) the likelihood of managing a locally owned resource in a sustainable manner is much higher (NRC, 1986, 2002). Situations with productive outcomes during one period of time, however, may not be robust when there is substantial out-migration of local residents due to increased market value of labor (Baker, 2005).

Rule Configurations. While philosophers, logicians, and legal scholars have focused heavily on the relationships between rules and likely behavior, there has been an unfortunate disconnect—until recently—between the self-conscious study of rules and how specific combinations of rules together with biophysical and community attributes generate efficient or inefficient, just or unjust, improving or deleterious patterns of interaction and outcomes (to name just a few of the evaluative criteria used by scholars). The effort to keep social science theories as simple as possible has deterred many from opening the black box called rules. Fortunately, considerable work both in political 
science (Shepsle, 1989; Miller, 1992; Levi, 1988; Tsebelis, 1990; Knight, 1992; Frohlich, Oppenheimer, and Young, 1971) and economics (North, 1990, 2005; Schmid, 2004; Eggertsson, 1990; Libecap, 1989; Greif, 2006; Hodgson, 2004) has now produced useful analyses that examine how specific rules affect the incentives and outcomes of a wide diversity of situations. So many specific rules have been examined, however, that cumulation has been slow. Further, while excellent work has been done on the impact of specific rules on outcomes, less research has focused on how resource users change rules (Faysse, 2005).

In our own effort to bring some order to the massive number of specific rules that one could analyze, we have clustered rules into seven broad types that could be present at any of three levels: operational situations, collective-choice situations, and constitutional situations. At each level, we have found it useful in our research to cluster rules according to the element of an action situation directly affected. Thus, boundary rules affect which participants can enter or leave (and under what conditions) a particular situation. Position rules create the positions (such as member of a committee, judge, dean, etc.) that participants hold. Choice rules assign action sets to positions filed by participants. Aggregation rules affect the level of control that individual participants exercise at a linkage within or across situations (must more than one agree to an action before it can be taken—such as the exchange of goods in a market). Information rules affect the level of information available to participants about actions and the link between actions and outcome linkages. Payoff rules affect the benefits and costs assigned to participants in light of the outcomes achieved and the actions chosen by the participant. Scope rules affect which outcomes may, must, or must not be affected within a situation. 
Thus, the components of each of these seven types of rules together provide a set of instructions about how to build each of the working parts of a situation and put them together in a structure.

\section{Confusing terms: Strategies, norms, and rules}

In our effort to understand institutional change, we must also confront three concepts that are frequently used interchangeably in social science literature: strategies, norms, and rules. Strategies are plans of actions that individuals adopt primarily for prudential reasons to achieve preferred outcomes in light of expectations of the likely strategies of others. One of the reasons why formal game theory has been so useful is that it enables the theorist to assume that all participants are fully rational. This means that all players will assume that all other players use the same model of the game and of each other as fully rational when they analyze a game. Thus, all will choose a best response to what they predict will be the best strategy chosen by others.

Norms represent preferences related to prescriptions about actions or outcomes that are not focused primarily on short-term materials payoffs to self. A participant who holds a truth-telling norm gains an internal reward (which can be modeled as an additional value added to their utility function) for telling the truth even when material payoffs would be greater when telling a lie (Crawford and Ostrom, 2005). While norms can evolve entirely internal to an individual, most norms are acquired in the context of the community in which the individual interacts frequently and change in this context. Thus, the chance that others in a relevant community may learn about a norm-breaking action strongly reinforces the internal value assigned to the norm conforming action (see 
Richerson and Boyd, 2005 for an important analysis of the role of shared norms in cultural evolution).

Rules are linguistic statements similar to norms, but rules carry an additional, assigned sanction if forbidden actions are taken and observed by a monitor. For rules to exist, any particular situation must be linked to a rule-making situation and some kind of monitoring and sanctioning must exist. ${ }^{6}$ Rules may be crafted in any of a wide diversity of collective-choice or constitutional-choice arenas in local, regional, national, or international domains. Contemporary scholarship tends to focus on rules that are formally prescribed by a national government, but we must understand the process of rule change at a community level as well.

\section{Representing rules, norms, and strategies}

In a formal game-theoretic analysis, rules are not represented in the game as they are part of the (temporarily) fixed factors that create the structure of the game in the first place. As Anatol Rapoport (1966) stressed long ago, once theorists understand the rules underlying the game sufficiently to model the game itself, the rules themselves disappear from further analysis. When doing fieldwork, however, the researcher must discover the rules being used. It is always a challenge to determine what the rules structuring patterns

of interaction are. Formal rules may exist in writing but not be followed or even known to the participants. In doing effective field research, one has to determine the "rules-in-use" by the participants if one wants to understand behavior and outcomes.

In a formal game, norms are frequently not represented at all. Crawford and Ostrom (2005) represent norms in the preference function of the players as positive or negative parameters attached to their utility function that are invoked either by internal 
feelings of regret or internal satisfaction (personal norms) or by external observation of their behavior (community norms) that lead to shame or pride. Shared norms can be sustained in a game theoretic analysis when players are able to exit a game upon discovery of a player who does not follow the norms (Orbell, Schwarz-Shea, and Simmons, 1984). In the field, one learns about shared norms when farmers tell you that "everyone here thinks it is shameful if ...." some statement like: "if one of us shirks when we all have to contribute a work day to clean our canals.”

\section{Changing rules as an evolutionary process}

Given the logic of combinatorics, it is impossible for public officials or for direct beneficiaries to conduct a complete analysis of the expected personal benefits or broader performance of all of the potential rule changes that could be made by the individuals served by a self-organized resource governance system trying to improve its performance. A similar impossibility also exists for biological systems-they evolve. Let us explore these similarities.

Self-organizing resource governance systems have two structures that are somewhat parallel in their function to the concepts of a genotype and a phenotype in biological systems. The genotypic structure characterizes the set of instructions encoded in DNA to produce an organism with a particular phenotypic structure. Phenotypic structures characterize an expressed organism—how bones, organs, and muscles develop, relate, and function in an organism in a particular environment. A rule configuration is parallel in function to a genotype. It is a set of instructions of how to produce the expressed situation or the structure of relationships among individuals that is also affected by the biophysical world and the kind of community or culture in which an 
action situation is located. The components of an action situation (or a game) characterize an expressed situation — how the number of participants, the information available, and their opportunities and costs create incentives, and how incentives lead to types of outcomes in a particular environment.

Rule systems can evolve. The evolution of cultural phenomena—including rules—involves different mechanisms from those involved in the evolution of species (Boyd and Richerson, 1985; Richerson and Boyd, 2005; Campbell, 1975; Nelson and Winter, 1982; Schmid, 2004; Greif and Laitin, 2004). As an evolutionary process, of course, there must be the generation of new alternatives, selection among new and old combinations of structural attributes, and retention of those combinations of attributes that are successful in a particular environment. In evolving biological systems, genotypic structures are changed through blind variation and not through design. ${ }^{7}$ Mechanisms such as crossover and mutation and the distribution of particular types of instructions depend on the survival rate of the phenotypes they produce in given environments.

Some changes in rules—-such as those resulting from memory loss—may resemble blind variation. Instead of relying entirely on blind variation, however, human agents frequently try to use reason and persuasion in their efforts to devise better rules (for themselves and their supporters or for a broader community. The process of choice, however, always involves experimentation. Self-organized resource governance systems use many types of decision rules to make collective choices ranging from deferring to the judgment of one person or elders, to using majority voting, to relying on unanimity (Ostrom, 1998; Walker et al., 2000). Rulers, who are strongly advantaged by rules that are disadvantageous for others, may continue to support the rules that generate substantial 
benefits for self. An external government may also exercise the collective choice of rules for a particular operational system.

In all of our efforts to study the performance of common-pool resource systems in the field, we have not found a particular set of collective-choice rules to be uniformly superior to others. We and other scholars have consistently found, however, that rules developed with considerable input of the resource users themselves tend to achieve a higher performance rate than systems where the rules entirely are determined by external authorities (Lam, 1998; Tang, 1992; Bardhan, 2000; Bardhan and Dayton-Johnson, 2002; Ostrom, Gardner, and Walker, 1994). Of course, whenever collective-choice processes facilitate some participants in an operational-choice situation gaining a disproportionately large share from a particular change in rules than others, the choice of new rules will tend to favor those advantaged by the rule change (Knight, 1992; Ensminger and Knight, 1997).

In order to study the evolution of rule systems, or at least the rules arrived at over time, an important methodological step is developing a method to representing rule configurations and rule changes. This will make possible the study of the relationship between rule configurations and the resulting operational level situations in the field and the lab. Thus, I now turn to the task of developing a preliminary method for studying rule change.

\section{A method for representing changes in norms and rules}

When one purchases a new recreational game to be played at home, it comes with a list of rules that are to be used by those playing the game along with the game board, the pieces, and/or the computer disk. Learning the rules used to govern and manage local natural 
resources is much more challenging than reading a list of recorded rules. Some rules may have evolved over multiple centuries, as those used in regulating the Bali irrigation systems described by Lansing (2006), the Alpine meadows described by Netting (1981), or customary law in England, Norway, and Africa (Orebech et al., 2005). The original rules were not written down nor have changes been recorded in many of these systems. Others may be of more recent origin, but still may not have been committed to written form (such as for many farmer-constructed and managed irrigation systems in developing countries) (Tang, 1992; Lam, 1998; Shivakoti and Ostrom, 2001).

In undertaking a meta analysis of a large set of case studies written about local fisheries and irrigation systems and in our current over-time study of more than 200 forests located in twelve countries, we have identified a very large number of rules actually used in practice (Ostrom, Gardner, and Walker, 1994; Hayes and Ostrom, 2005; Gibson, Williams, and Ostrom, 2005). Because the diversity of potential rules is so large, we should not assume that the choice of institutional rules to improve the performance of common-pool resource institutions—or any other set of rules—is a process of designing optimal rules (Ostrom, 2007). We need to understand the rule evolution process as involving an effort to tinker with a large number of component parts (see Jacob, 1977). Those who tinker with any tools—including rules—-try to find combinations that work together more effectively than other combinations. Policy changes are experiments based on more or less informed expectations about potential outcomes and the distribution of these outcomes for participants across time and space (Campbell, 1969, 1975). Whenever individuals agree to add a rule, change a rule, or adopt someone else's proposed rule set, they are conducting a policy experiment. ${ }^{8}$ Further, the complexity of the ever-changing 
biophysical world, combined with the complexity of rule systems, means that any proposed rule change faces a non-trivial probability of error. ${ }^{9}$

\section{Default conditions}

Let us now focus on what is being changed when appropriators change rules. What do these underlying building blocks for creating an action situation at an operational level look like? Before we can turn to the rules themselves, however, we have to ask how to represent a "none-rule." What should we think about the structure of a game in the absence of any rules? This question is particularly important due to the configurational nature of rules. One needs to know the basic contents of a full rule configuration, rather than just a single rule, to infer both the structure of the resulting situation and the likely outcome of any particular rule change. Knowing that farmers use majority rule without knowing for what choices this rule is utilized, provides insufficient information for understanding structure and outcomes.

If irrigators are involved in appropriating water in a "state of nature," one can think of a set of default conditions that one would use in constructing such a game. The seven default conditions list on Table 2 are those that would be used by a participant in, or an observer of, a situation with no existing rules. Thus, this set defines the initial conditions of a common-law legal system. ${ }^{10}$ If one wants to analyze changing rules, the initial situation before any rules are established is the base situation. Hobbes's analysis of the state of nature and Garrett Hardin’s (1968) analysis of “The Tragedy of the Commons" implicitly relied on the above set of default conditions as structuring the situations they analyzed.

(Table 2 about here) 


\section{Changing the default conditions}

The default conditions are self consciously changed to rules in a linked collective-choice situation that makes rule changes for a particular operational situation. For an irrigation system governed by the farmers it serves, for example, the collective-choice situation is likely to be an annual meeting of all of the farmers or a Water User Committee elected by the farmers. For governmental systems, the rules may be prescribed by an administrative agency of the state or national government involved. In some situations, multiple collective-choice organizations compete to make the rules for an operational situation, but we will not address that problem in this paper.

In an earlier paper (1995), I examined the linkage between collective-choice decisions about rules for an operational irrigation system by formalizing the resultant games and the likely equilibria outcomes in the irrigation games structured by each rule change. The paper illustrates that the biophysical world is as important as the rules in affecting outcomes and can lead to strong heterogeneity among participants. Trying to find rules that work when the difference between upstream and downstream farmers is large is a classic example of the challenge of designing fair rules when participants bear different streams of benefits and costs. Given the examples in the earlier paper, what I want to do in the rest of this section is to develop a method for analyzing rule changes over time.

In Table 3, I have arrayed a set of three "proto” rule statements for each of the seven types of rules discussed above for an operational-level irrigation system. ${ }^{11}$ Three proto rule statements for each type of rules is a very small set given the large number of rules of each type we have recorded from case studies written about resource government 
institutions in the world. I am trying at this point to develop a method for recording and analyzing institutional change rather than examining the full inventory of all rules already identified. I refer readers to prior work where a large number of each type of rule is discussed (Tang, 1992; Ostrom, Gardner, and Walker, 1994; Ostrom, 1999, 2005). (Table 3 about here)

I will draw on, and slightly modify, the method that Blomquist, Schlager, Tang, and I used in coding rules for the meta-analysis reported in the third section of Ostrom, Gardner, and Walker (1994) and in Ostrom (1999). Rules that have frequently been used in governing irrigation systems are listed first in Table 3 and then arrayed as columns in the rule inventory of Table 4 (see Tang, 1992 for a description of these rules). The inventory is divided into seven broad fields with specific rule statements (described in Table 3) that might be a norm or a rule or the absence of either prescription. ${ }^{12}$ If no norm or rule is used at all, the rule statement is coded 0 . If a norm has evolved that participants "should" follow a particular proto-prescription an S will be entered for that protoprescription. If a rule has been established, I will code that statement as either:

$\mathrm{R}=$ Required; $\mathrm{P}$ = Permitted; or $\mathrm{F}$ = Forbidden

(Table 4 about here)

This method will be used to examine processes of rule change and the fit of rules to biophysical and community characteristics of a particular setting. In Table 4, I have used the numbering system of Table 3 for the columns. Thus, the three columns under the heading Boundary Rules in Table 4 represent the three rules listed under that category in Table 3. The other numeric column headings on Table 4 are similarly described in Table 3. 
The first row of Table 4 represents a Rule Configuration at T1 when there are no norms or rules in use—all entries are zeros. Thus, Row 1 represents a lawless "state of nature" that Hardin (1968) envisioned leading to a "tragedy" of the commons. If one were to model the resulting appropriation situation as a formal game (assuming that the farmers live next to a water source have a high demand for the water), the Nash equilibrium would be an inefficient level of water withdrawal (Ostrom, Gardner, and Walker, 1994: chap. 3). Thus, the prediction for behavior and outcomes in an irrigation game constituted by the total absence of normative prescriptions is that every farmer grabs as much water as they can when it is available. This would mean that the farmers located at the head end of a system would obtain most of the water. The overall crop yield for the system as a whole would be below the yield that would be feasible if water were allocated to all of the parcels adjacent to the system.

\section{Relying on norms}

For very simple and isolated systems, the farmers located adjacent to a system might develop a simple set of norms over time that would lead to a water rotation system along the canal. If there were 14 farmers and they agreed on a simple set of norms such as: only the 14 farmers should take water from system, no watering at night, and each farmer takes a half-a-day turn before turning the water distribution over to the next farmer, it is conceivable that such a set of norms—coded as S in Row 2—might suffice for some time. They would need three norms: (1) only the 14 adjacent farmers should use the irrigation water-B1, (2) they should rotate water distribution during the daylight hours following a specific schedule $-\mathrm{C} 3$, and (3) everyone should maintain the canal in front of their own farm, and should pitch in and help in times of emergency repair-Y3. 
Such a simple norm-based system might survive for a long time if the land were relatively flat so headenders did not have a strong advantage given to them by nature, if the land was always inherited by one child (rather than being divided each generation—a general inheritance rule for a larger community ${ }^{13}$ ), if no one sold their land to outsiders, and if the system was relatively isolated from changes in the value of land, labor, or commodities. These are four large "ifs.” Robert Netting (1974) described such a system that he observed in his fieldwork in Switzerland. I do not know of any other irrigation system where the farmers rely on norms alone. Given the high value of irrigation water for many families (since their survival depends on their getting enough water), conflicts can easily arise over who takes water under what conditions. Conflicts undermine shared norms if they are not resolved.

\section{Changing rules within collective-choice arenas}

Conflict could arise and stimulate changes to the use of rules in this simple system in many different ways. As an example, if one of the fourteen farming households sold their land, a new resident might argue that they bought the land in order to grow a crop that requires more water than the other farmers in the system. If they began to take water at night or try to take a longer turn than the norm, conflict would certainly be generated. This would likely lead to a meeting of the farmers. The farmers might then decide to organize a Water Users Association and, in a collective-choice situation within the new association, make four new rules:

1. formalize the rotation system that had evolved only sustained by norms (a change from S to R for allocation rule C3); 
2. create a new position of official monitor and that each household rotates into that position on a day when they do not take water following a pre-determined schedule (a change from 0 to $\mathrm{R}$ for position rule P1);

3. create a new rule that both farmers must be present at the time when the water turn changes from one farmer to the other (a change from 0 to $\mathrm{R}$ in aggregation rule $\mathrm{A} 1)$; and

4. impose a penalty on any farmer who does not follow the first three rules (a change from 0 to $\mathrm{R}$ in payoff rule $\mathrm{Y} 1$ ).

They could keep the norm about contributing labor for maintaining the canal.

Row 3 (T3) represents this new set of rules (and the one remaining norm) that the Water Users Association might devise in trying to establish some initial rules to keep their water allocation system operating as it had using only norms. If, however, the new farmer was very wealthy and had considerable political power, they might instead fear challenging his demands and give him one day a week to take as much water as he wanted. In T4, they might decide to allocate water on a fixed percentage basis—-giving the powerful farmer the percentage of water he demanded, and all of the other 13 farmers an equal percentage of the remaining water. This would represent a change in the allocation rule from C3 being required to $\mathrm{C} 1$ now being required and a formula devised to keep the powerful farmer happy while allocating the rest of the water to the other 13 players (see Row 4).

Over time, farmers in the Water Users Association might find themselves in a changing economic situation in which more and more settlers move into the region. New settlers are unlikely to know the norms of who can use how much water from which 
water source. Members of the water association may then find some strangers taking water from their system. That may lead them to decide at $\mathrm{T} 5$ to change from a norm, regarding who can use the water, to a rule that requires a farmer to own land within a specified region to take water from this source (B1 would change from S to R if that rule were adopted as shown in Row 5). The official monitor that they had already created could then be charged with evicting anyone not among the authorized land owners if found using water.

Once a collective-choice arena has been established, rules may sometimes be changed as a result of proposals submitted in that arena and efforts made at conscious design using whatever aggregation rule they have settled upon for making operational rules. That rule will, of course, affect the type of rules selected—if a small clique can make rules at a collective-choice level, one can expect to see them try to change rules that advantage the clique (Ostrom, 1999; Ensminger and Knight, 1997). Well-entrenched governing cliques are not very likely to search out more effective rules for the system and may lead a system to benefit only themselves. Given the large number of potential rules that could be used at an operational level, however, resource users (or a governing clique) never fully search the potential rule inventory and pick the one set that is optimal for the system (or for any subset of farmers). If the farmers are relatively homogeneous in regard to resources and in regard to the likely results of a rule change, they may just tinker with their rules until they find a good combination for their setting, but this may take multiple years. If external factors do not change during a period of rule trial-and-error, they may eventually find a relatively well-operating set of rules for their conditions. 
If, however, the farmers are heterogeneous in regard to their location, assets, and other variables—as discussed in Ostrom (1995) — then they may find themselves faced with proposals made by some farmers that advantage the proposing farmers and disadvantage others. In a system where the maintenance costs are relatively low, headenders on a canal may demand that they have prior rights to water and then take as much water as they can grab and not worry about water getting to the tail end of the system or about getting the other farmers to help with maintenance. If the costs of maintaining a system are very high, however, headenders cannot afford this kind of asymmetric rule. They need the tailenders and would be willing to share water equitably so long as the tailenders were also willing to share maintenance equitably (see Ostrom, 1995: figs. 5 and 6).

\section{Other processes leading to changes in the rules of a system}

In addition to an effort to improve the operational rules of a system in a relatively selfconscious process, other processes can affect the evolution of a rule system over time (see Schmid, 2004: chap. 13 for an excellent review of processes of institutional change). In systems where rules are not written and some rules are not used repeatedly in everyday circumstances, rules can be forgotten. Memory loss can also occur in systems where there are a very large number of rules and no one can "remember" them all without extensive research. Some participants may "forget" a rule in a strategic move that advantages them with the hope that other may have forgotten this rule and not challenge them for breaking it.

Non-enforcement of rules may be a mechanism that leads to a "memory loss" or simply the withering away of structure that had been agreed upon. Rules are composed of 
mere words and, as Vincent Ostrom (1997) has frequently pointed out, words are not always understood by everyone with the same meaning. A guard may not understand the rules the same way as users or may interpret rules that place heavy costs of the guard differently than those rules that involve low costs to enforce.

Conflict over the interpretation of rules is also a process that can frequently lead to changes. If there is a regularized procedure for hearing conflict and reaching solutions that are accepted by participants as legitimate, rules may be added, taken away, or modified as a result of such procedures. In common-law settings, one can expect those disadvantages by current rules to challenge them and even continue to challenge initial decisions against them until they gain an interpretation favorable to their situation (Stakes, 2004).

Imitation of rules used by others is also a likely process leading to rule evolution over time especially if the farmers from multiple irrigation systems regularly interact in a local market or other regular meeting place. Imitation is one of the important processes identified as underlying cultural evolution (Richerson and Boyd, 2005). Imitation may lead to improved performance when the indicators of success used by "copiers” are reliable and the systems are relatively similar, but imitation can also lead to decreases in performance.

\section{Conditions likely to enhance learning and productive rule evolution}

From post-empirical research, one can begin to identify the conditions and processes likely to enhance the learning process of farmers and others making institutional decisions regarding irrigation systems (or other local resources) and the likelihood of an institutional evolutionary process to lead to better, as contrasted to poorer outcomes. In 
general, one would expect the rules structuring operational interactions within similar types of situations—-such as smaller irrigation systems in a region—-to evolve toward more productive outcomes when:

- most participants affected have some voice in proposing rule changes and making decisions about rule changes;

- most participants within systems have sufficiently large payoffs at stake that they are willing to invest in the transaction costs of searching, debating, and learning about better options;

- participants with the largest stakes have an interest broadly congruent with increased productivity for the system. (This will tend to occur in an irrigation system when the richest farmers are located toward the tail end, are dependent on the others to contribute resource toward the maintenance of the system, or when big differences in the wealth and power of the farmers are not present);

- internal processes within systems have generated substantial variety in the rules used to structure interactions within different systems leading to a range of performance in regard to agricultural productivity, maintenance of the physical capital, and distribution of income to participants;

- participants are in a social and economic environment where they can learn from successes and failures of others (such as, regular meeting places where farmers gossip about the problems they are facing, existence of officials who are charged with helping farmers learn how to get better productivity from their systems (e.g. extension agents or NGOs); federations of local water associations who meet annually). 
- the participants have developed regular procedures for reviewing their experience over time, revising rules and procedures when they evaluate that they could be improved, and recording their changes so that they gain a good history of what they have tried and what results they obtained;

- the systems are in a political environment that encourages local autonomy but also provides oversight regarding corruption and accountability as well as conflict resolution; and

- biophysical disturbances happen frequently enough so that participants learn how to cope with them rather than occurring only occasionally leaving farmers unprepared.

For rule configurations to evolve, there must be processes that: (1) generate variety, (2) select rules based on relatively accurate information about comparative performance in a particular environment, and (3) retain rules that perform better in regard to criteria such as efficiency, equity, accountability, and sustainability.

It would be naive to assume that any evolutionary process will always lead to better outcomes. In biological systems, competition among populations of diverse species led to the weeding out of many individuals over time that were out-competed for mates and food in a given environment. Evolutionary processes can also lead to equilibria imposing higher costs on some species and eliminating others. One should not expect that all locally governed systems will eventually find effective rule configurations. Some will experiment with rule configurations that are far from optimal. And, if the leaders of these systems are somehow advantaged by these rules, they may resist any effort to change. 
In our future research, we hope to use the approach outlined above to study how rules evolved in multiple cases and then to use agent-based modeling to explore diverse initial conditions and change over time. We know there are both better and worse processes of institution change and hope to build on and test the above speculations so as to develop a more solid basis for encouraging processes more likely to lead to improved performance than has been the dominant way of thinking about institution change and development.

\section{Conclusion: The danger of institutional monocultures}

The conditions posited above as likely to enhance the quality of institutional evolution have not characterized irrigation investments in most of the developing world during the last several decades. The monetary investment in irrigation has been huge, however. The World Bank alone contributed around $\$ 10.6$ billion in loans for irrigation projects between 1983 and 1999 (Pitman, 2002: 12; see also Yudelman, 1985). International donors were contributing about $\$ 2$ billion per year during the 1990s (Winpenny, 1994). These investments have not generated high returns. Hugh Turral (1995: 1) captured the judgment of many analysts by concluding that "irrigation schemes have often underperformed in economic terms, and field research has highlighted substantial shortcomings in management (operation and maintenance), equity, cost-recovery and agricultural productivity.” Some critics, like William Easterly (2001), assert that most of the funding spent by international aid agencies since the 1960s has tragically not achieved promised results (see also Gibson et al., 2005).

As Peter Evans (2004: 31-32) articulates: "Currently, the dominant method of trying to build institutions that will promote development is to impose uniform 
institutional blueprints on the countries of the global South—a process which I call 'institutional monocropping'." Even worse than the initial problems of having the wrong institutions imposed almost everywhere is the "lock in" that can occur when powerful individuals gain advantage from such institutions leading to major problems of path dependence (Arthur, 1989). The powerless and helpless are the ones who pay the big costs.

Lant Pritchett and Michael Woolcock (2004) develop a complementary analysis to that of Peter Evans. They puzzle over the problem of new solutions when the dominant Weberian paradigm was the solutions used by development agencies, and now it is the problem confronting anyone concerned about development. They graphically describe the systematic failure of development agencies to improve any services to rural areas including those related to irrigation. "Donor activity often amounts to sending 'experts' who operate institutions in 'Denmark' to design institutions in 'Djibouti.' At best, this would be like sending a cab driver to design a car" (ibid.: 199).

Institutional monocropping generates systems that have little variety in their formal rules in environments with substantial variety in the ecological regions in which they are situated. While expert knowledge can be a great asset in the design and implementation of local resource systems, simply imposing a uniform set of formal rules and ignoring local ecological and social knowledge does not produce the variety needed to learn from experience.

So how can we get out of the kind of institutional monocropping that currently dominates much of social science thinking as well as that of development agencies? There is obviously not one way to solve this problem! As academics, we can help by 
being willing to develop more complex theories for explaining the behavior of humans in widely divergent settings (Wilson, 2002; Schmid, 2004). We do not need to be complex, however, just to be complex, but we do need to get over our simplicity hang-ups.

Obviously, our theories will always be simpler than the world's we study or we are trying to reproduce the world itself rather than a theory of the world. But given the complex nested systems of the biophysical world, we need to develop a social science of complex, nested systems (Ostrom, 2007). Allan Schmid has contributed greatly to this endeavor, and we all have benefited from his extensive research on diverse institutions and their change over time. 


\section{Notes}

Paper presented at a Workshop in Honor of the Career of Professor A. Allan Schmid on "Various Approaches to Assessing the Evolution and Impact of Alternative Institutional Structures,” Michigan State University, East Lansing, 15-17 March 2007. A much earlier version was presented at the symposium on "Who Should Do What in Environmental Governance,” held at the Porto Conte Ricerche centre in Sardina, Italy, 21-24 September 2005, and at the "Future of the Social Science II Conference, the Cornell Club, New York City, 6-8 October 2005. Support from the National Science Foundation and the MacArthur Foundation is deeply appreciated. Thanks also to the colleagues who have given me excellent feedback on earlier drafts-Xavier Basurto, Sue Crawford, Nicolas Faysse, Robert Holahan, Marco Janssen, Filippo Menczer, and Brian Steed-and to Patty Lezotte for all of her great spirit and editing skills.

${ }^{1}$ Marty Anderies, Robert Goldstone, Marco Janssen, Filippo Menczer, Juan-Camilo Cardenas, and Francois Bousquet are all senior researchers working together on this project (see http://www.public.asu.edu/ majansse/dor/nsfhsd.htm).

${ }^{2}$ Readers who would like to gain an overview of the type of research undertaken at the Workshop over the years may wish to look at the 2005 special issue of the Journal of Economic Behavior and Organization edited by Peter J. Boettke on "Polycentric Political Economy” (vol. 57, no. 2).

${ }^{3}$ Currently, there is considerable rebel activity in Nepal that is disrupting many activities especially in the countryside and creating many tragedies for Nepali farmers. The 
findings discussed in this paper are based on data most of which was collected in earlier peaceful times.

${ }^{4}$ Readers who wish to dig deeper are encouraged to read Lam (1998), Joshi et al. (2000), and Shivakoti and Ostrom (2001) and the extensive references cited therein.

${ }^{5}$ See Ostrom (2005) for a much more extended discussion of the IAD framework than is feasible here.

${ }^{6}$ Sue Crawford and I have worked hard over more than a decade to clarify the close link between strategies, norms, and rules. We have developed a grammar that can be used to "parse” each of them. For example, each rule can be parsed into five components that specify: (1) the attributes of a participant (such as age, education, gender) affected by a rule; (2) the deontic modal verb of the rule which include "may" (permitted), "must” (obliged), and "must not” (forbidden); (3) where the rule aims — at the set of potential actions or the outcomes of the situation; (4) the conditions specifying when and where an action or outcome is permitted, obligatory, or forbidden, and (5) the consequences specified for not following a rule (the “or else”) (see Crawford and Ostrom, 2005). For core work on deontic logic, see Hilpinen (1981) and von Wright (1951, 1963). ${ }^{7}$ Of course, genetically modified organisms are currently being designed, but this is a very recent phenomena.

${ }^{8}$ Officials may also be tinkering with rules so as to increase payoffs to themselves or their supporters. Thus, policy experiments may not produce announced expected outcomes due to motivations other than improving these outcomes as well as the challenge of prediction in such complex systems. 
${ }^{9}$ When only a single governing authority makes decision about rules for an entire region, policymakers have to experiment simultaneously with all of the common-pool resources within a jurisdiction with each policy change. And, once a change has been made and implemented, further changes will not be made rapidly. The process of experimentation will usually be slow, and information about results may be contradictory and difficult to interpret. Thus, an experiment that is based on erroneous data about one key structural variable or one false assumption about how actors will react, can lead to a very large disaster. In any design process where there is substantial probability of error, having redundant teams of designers has repeatedly been shown to have considerable advantage (see Landau, 1969, 1973; Bendor, 1985; Carlson and Doyle, 2002). The need for extensive experimentation to learn how combinations of variables work together (or, are not compatible) makes it extremely challenging to design global systems. At the global level, there is only one system on which to experiment (Ostrom et al., 1999). ${ }^{10}$ In a Roman law country, the default conditions would be entirely different since Roman law systems presume that most things are forbidden unless specifically permitted. ${ }^{11}$ The proto rule statements for boundary, choice, and payoff rules are the rules that Tang (1992) identified as the most frequently observed rules in his meta analysis of irrigation cases located in many different countries. The proto rule statements for the other rules are derived from extensive field research regarding irrigation systems in many countriesparticularly Nepal. They are the rules that I have frequently encountered (see Shivakoti and Ostrom, 2001; Joshi et al,. 2000).

${ }^{12}$ We have long relied on the symbols used in deontic logic for modal operators. For background, see Hilpinen (1981) and von Wright (1951, 1963). 
${ }^{13}$ The rules set for any one interaction situation are always affected by rules determined by larger regimes—-such as the inheritance rules in force. 


\section{References}

Acheson, James (2003), Capturing the Commons: Devising Institutions to Manage the Maine Lobster Industry, Hanover, NH: University Press of New England.

Acheson, James and Gardner, Roy (2004), “Strategies, Conflict, and the Emergence of Territoriality: The Case of the Maine Lobster Industry,” 106(2) American Anthropologist, 296-307.

Agrawal, Arun and Gupta, K. (2005), “Decentralization and Participation: The Governance of Common Pool Resources in Nepal’s Terai,” 33(7) World Development, 1101-1114.

Alchian, Armen A. (1950), “Uncertainty, Evolution, and Economic Theory,” 58(3) Journal of Political Economy, 211-221.

Anderies, John M., Janssen, Marco and Ostrom, Elinor (2004), “A Framework to Analyze the Robustness of Social-Ecological Systems from an Institutional Perspective,” 9(1) Ecology and Society, 18.

APROSC and JMA (1995), Nepal Agriculture Perspective Plan (Final Report)-Main Document, Kathmandu: Agricultural Projects Service Center and John Miller Associates, Inc.

Arthur, W. B. (1989), “Competing Technologies, Increasing Returns, and Lock-in by Historical Events,” 99 Economic Journal, 116-131.

Axelrod, Robert (1984), The Evolution of Cooperation, New York: Basic Books.

Baker, M. (2005), The Kuhls of Kangra: Community Managed Irrigation in the Western Himalaya, Seattle: University of Washington Press. 
Bardhan, P.K. (2000), “Irrigation and Cooperation: An Empirical Analysis of 48 Irrigation Communities in South India," 48(4) Economic Development and Cultural Change, 847-865.

Bardhan, P.K. and Dayton-Johnson, J. (2002), “Unequal Irrigators: Heterogeneity and Commons Management in Large-Scale Multivariate Research,” in National Research Council, Committee on the Human Dimensions of Global Change, Elinor Ostrom, Thomas Dietz, Nives Dolšak, Paul Stern, Susan Stonich, and Elke Weber (eds), The Drama of the Commons, Washington, D.C.: National Academy Press, 87-112.

Bendor, Jonathan (1985), Parallel Systems: Redundancy in Government, Berkeley: University of California Press.

Benjamin, Paul, Lam, Wai-Fung, Ostrom, Elinor and Shivakoti, Gganesh (1994), Institutions, Incentives, and Irrigation in Nepal, Decentralization: Finance \& Management Project Report, Burlington, VT: Associates in Rural Development. Berkes, Fikret, Colding, Johan and Folke, Carl (2003), Navigating Social-Ecological Systems: Building Resilience for Complexity and Change, Cambridge: Cambridge University Press.

Blomquist, William (1992), Dividing the Waters: Governing Groundwater in Southern California, Oakland, CA: ICS Press.

Bousquet, F., Barreteau, O., d’Aquino, P., Etienne, M., Boissau, S., Aubert, S., Le Page, C., Babin, D. and Castella, J.-C. (2002), “Multi-Agent Systems and Role Games: Collective Learning Processes for Ecosystem Management," in Marco Janssen (ed.), 
Complexity and Ecosystem Management: The Theory and Practice of Multi-Agent Systems, Cheltenham, UK: Edward Elgar.

Boyd, Robert and Richerson, Peter J. (1985), Culture and the Evolutionary Process, Chicago: University of Chicago Press.

Campbell, Donald T. (1969) “Reforms as Experiments,” 24(4) American Psychologist, 409-429.

Campbell, Donald T. (1975), “On the Conflicts between Biological and Social Evolution and between Psychology and Moral Tradition,” 30(11) American Psychologist, 1103-1126.

Cardenas, Juan-Camilo (2000), “How Do Groups Solve Local Commons Dilemmas? Lessons from Experimental Economics in the Field,” 2 Environment, Development and Sustainability, 305-322.

Cardenas, Juan-Camilo and Ostrom, Elinor (2004), "What Do People Bring into the Game? Experiments in the Field about Cooperation in the Commons,” 82(3) Agricultural Systems, 307-326.

Cardenas, Juan-Camilo, Stranlund, John and Willis, Cleve (2000), "Local Environmental Control and Institutional Crowding-Out,” 28(10) World Development, 17191733.

Carlson, Jean M. and Doyle, John (2002), “Complexity and Robustness,” 99 Proceedings of the National Academy of Science, 2358-2545.

Cox, James (2004), “How to Identify Trust and Reciprocity,” 45 Games and Economic Behavior, 260-281. 
Crawford, Sue E.S. and Ostrom, Elinor (2005), “A Grammar of Institutions,” in Elinor Ostrom (ed.), Understanding Institutional Diversity, Princeton, NJ: Princeton University Press; originally published in 89(3) American Political Science Review (1995), 582-600.

Easterly, William (2001), The Elusive Quest for Growth: Economists’ Adventures and Misadventures in the Tropics, Cambridge: Cambridge University Press.

Eggertsson, Thrainn (1990), Economic Behavior and Institutions, New York: Cambridge University Press.

Ensminger, Jean and Knight, Jack (1997), “Changing Social Norms: Common Property, Bridewealth, and Clan Exogamy,” 38(1) Current Anthropology, 1-24.

Evans, Peter (2004), “Development as Institutional Change: The Pitfalls of Monocropping and the Potentials of Deliberation,” 39(4) Studies in Comparative International Development, 30-52.

Faysse, Nicolas (2005), “Coping with the Tragedy of the Commons: Game Structure and Design of Rules,” 19(2) Journal of Economic Surveys, 239-261.

Frohlich, Norman, Oppenheimer, Joe and Kurki, Anja (2004), “Modeling OtherRegarding Preferences and an Experimental Test,” 119(1-2) Public Choice, 91117.

Frohlich, Norman, Oppenheimer, Joe and Young, Oran (1971), Political Leadership and Collective Goods, Princeton, NJ: Princeton University Press.

Gardner, Roy and Ostrom, Elinor (1991), “Rules and Games,” 70(2) Public Choice, 121149. 
Gautam, U., Agrawal, N.K. and Subedi, R. (eds) (1992), Nepal: Managing Large Surface Irrigation Project: A Participatory Review, Study Document NEP/89/006, Kathmandu, Nepal: Department of Irrigation and Consolidated Management Services.

Gibson, Clark, Andersson, Krister, Ostrom, Elinor and Shivakumar, Sujai (2005), The Samaritan's Dilemma: The Political Economy of Development Aid, Oxford, UK: Oxford University Press.

Gibson, Clark, McKean, Margaret and Ostrom, Elinor (eds) (2000), People and Forests: Communities, Institutions, and Governance, Cambridge, MA: MIT Press.

Gibson, Clark, Williams, John and Ostrom, Elinor (2005), “Local Enforcement and Better Forests,” 33(2) World Development, 273-284.

Gintis, Herbert (2004), “The Genetic Side of Gene-Culture Coevolution: Internalization of Norms and Prosocial Emotions," 53(1) Journal of Economic Behavior and Organization, 57-67.

Greif, Avner (2006), Institutions and the Path to the Modern Economy, Cambridge: Cambridge University Press.

Greif, Avner and Laitin, David (2004), “A Theory of Endogenous Institutional Change,” 98(4) American Political Science Review, 633-652.

Güth, Werner and Kliemt, Hartmut (1998), “The Indirect Evolutionary Approach: Bridging the Gap between Rationality and Adaptation,” 10(3) Rationality and Society, 377-399.

Hardin, Garrett (1968), “The Tragedy of the Commons,” 162 Science, 1243-1248. 
Hayes, Tanya M. and Ostrom, Elinor (2005), “Conserving the World’s Forests: Are Protected Areas the Only Way?,” 38(3) Indiana Law Review, 595-617. Hilpinen, Risto (ed.) (1981), New Studies in Deontic Logic: Norms, Actions, and the Foundations of Ethics, Dordrecht, Holland: D. Reidel.

Hilton, Rita (1990), Cost Recovery and Local Resource Mobilization: An Examination of Incentives in Irrigation Systems in Nepal, Decentralization: Finance \& Management Project Report, Burlington, VT: Associates in Rural Development. Hodgson, Geoffrey M. (2004), The Evolution of Institutional Economics: Agency, Structure and Darwinism in American Institutionalism, London: Routledge. Hughes, Terence P., Bellwood, David R., Folke, Carl, Steneck, Robert S. and Wilson, James (2005), “New Paradigms for Supporting the Resilience of Marine Ecosystems,” 20(7) TRENDS in Ecology and Evolution, 380-386.

Jacob, Francois (1977), “Evolution and Tinkering,” 196(4295) Science, 1161-1166.

Janssen, Marco (ed.) (2002), Complexity and Ecosystem Management: The Theory and Practice of Multi-Agent Systems, Cheltenham, UK: Edward Elgar.

Janssen, Marco. (2007), “Coordination in Irrigation Systems: An Analysis of the Lansing-Kremer Model of Bali,” 93 Agricultural Systems, 170-190.

Janssen, Marco, Anderies, John M., and Ostrom, Elinor (2007), “Robustness of SocialEcological Systems to Spatial and Temporal Variability,” 20(4) Society and Natural Resources, 307-322.

Janssen, Marco, Goldstone, Robert, Menczer, Filippo and Ostrom, Elinor (2006), “Effect of Rule Choice in Dynamic Interactive Spatial Commons,” Working Paper. Tempe: Arizona State University. 
Janssen, Marco and Ostrom, Elinor (2006), “Adoption of a New Regulation for the Governance of Common-Pool Resources by a Heterogeneous Population,” in Jean-Marie Baland, Pranab Bardhan, and Samuel Bowles (eds), Inequality, Cooperation, and Environmental Sustainability, Princeton, NJ: Princeton University Press.

John, P. (2003), “Is There Life after Policy Streams, Advocacy Coalitions, and Punctuations: Using Evolutionary Theory to Explain Policy Change?,” 31(4) Policy Studies Journal, 481-498.

Joshi, Neeraj N., Ostrom, Elinor, Shivakoti, Ganesh, and Lam, Wai-Fung (2000), “Institutional Opportunities and Constraints in the Performance of FarmerManaged Irrigation Systems in Nepal,” 10(2) Asia-Pacific Journal of Rural Development, 67-92.

Kiser, Larry and Ostrom, Elinor (1982), “The Three Worlds of Action: A Metatheoretical Synthesis of Institutional Approaches,” in Elinor Ostrom (ed.), Strategies of Political Inquiry, Beverly Hills, CA: Sage.

Knight, Jack (1992), Institutions and Social Conflict, New York: Cambridge University Press.

Lam, Wai-Fung (1998), Governing Irrigation Systems in Nepal: Institutions, Infrastructure, and Collective Action, Oakland, CA: ICS Press.

Lam, Wai-Fung and Shivakoti, Ganesh (2002), “Farmer-to-Farmer Training as an Alternative Intervention Strategy,” in Ganesh Shivakoti and Elinor Ostrom (eds), Improving Irrigation Governance and Management in Nepal, Oakland, CA: ICS Press. 
Lam, Wai-Fung, Lee, Myungsuk and Ostrom, Elinor (1994), “An Institutional Analysis Approach: Findings from the NIIS on Irrigation Performance,” in Jennifer Sowerwine, Ganesh Shivakoti, Ujjwal Pradhan, Ashutosh Shukla, and Elinor Ostrom (eds), From Farmers’ Fields to Data Fields and Back: A Synthesis of Participatory Information Systems for Irrigation and Other Resources, Colombo, Sri Lanka: International Irrigation Management Institute, and Rampur, Nepal: IAAS, 69-93.

Landau, Martin (1969), “Redundancy, Rationality, and the Problem of Duplication and Overlap,” 29(4) Public Administration Review, 346-358.

Landau, Martin (1973), “Federalism, Redundancy, and System Reliability,” 3(2) Publius, 173-196.

Lansing, J. Stephen (1991), Priests and Programmers: Technologies of Power in the Engineered Landscape of Bali, Princeton, NJ: Princeton University Press.

Lansing, J. Stephen (2006), Perfect Order: Recognizing Complexity in Bali, Princeton, NJ: Princeton University Press.

Lansing, J. Stephen and Kremer, James (1993), “Emergent Properties of Landscape,” 95(1) American Anthropologist, 97-115.

Levi, Margaret (1988), Of Rule and Revenue, Berkeley: University of California Press. Libecap, Gary (1989), Contracting for Property Rights, New York: Cambridge University Press.

Miller, Gary (1992), Managerial Dilemmas: The Political Economy of Hierarchy, New York: Cambridge University Press. 
Nelson, Richard and Winter, Sidney (1982), An Evolutionary Theory of Economic Change, Cambridge, MA: Harvard University Press.

Netting, Robert McC. (1974), “The System Nobody Knows: Village Irrigation in the Swiss Alps,” in Theodore Downing and McGuire Gibson (eds), Irrigation's Impact on Society, Tucson: University of Arizona Press.

Netting, Robert McC. (1981), Balancing on an Alp: Ecological Change and Continuity in a Swiss Mountain Community, New York: Cambridge University Press.

North, Douglass C. (1990), Institutions, Institutional Change and Economic Performance, New York: Cambridge University Press.

North, Douglass C. (2005), Understanding the Process of Institutional Change, Princeton, NJ: Princeton University Press.

NRC (National Research Council) (1986) Proceedings of the Conference on Common Property Resource Management, Washington, D.C.: National Academy Press. NRC (National Research Council) (2002) The Drama of the Commons, Committee on the Human Dimensions of Global Change, Elinor Ostrom, Thomas Dietz, Nives Dolšak, Paul Stern, Susan Stonich, and Elke Weber (eds), Washington, DC: National Academy Press.

Orbell, John M., Schwarz-Shea, Perry and Simmons, Randy T. (1984), “Do Cooperators Exit More Readily Than Defectors?,” 78 American Political Science Review, $147-162$.

Orebech, Peter, Bosselman, Fred, Bjarup, Jes, Callies, David, Chanock, Martin, and Petersen, Hanne (2005), The Role of Customary Law in Sustainable Development, Cambridge University Press. 
Ostrom, Elinor (1990), Governing the Commons: The Evolution of Institutions for Collective Action, New York: Cambridge University Press.

Ostrom, Elinor (1992), Crafting Institutions for Self-Governing Irrigation Systems, San Francisco, CA: ICS Press.

Ostrom, Elinor (1995) “Self-Organization and Social Capital,” 4(1) Industrial and Corporate Change, 131-159.

Ostrom, Elinor (1998), “A Behavioral Approach to the Rational Choice Theory of Collective Action,” 92(1) American Political Science Review, 1-22.

Ostrom, Elinor (1999) “Coping with Tragedies of the Commons,” Annual Review of Political Science, 2: 493-535.

Ostrom, Elinor (2005), Understanding Institutional Diversity, Princeton, NJ: Princeton University Press.

Ostrom, Elinor (2007), “The Challenge of Going beyond Panaceas,” Bloomington: Indiana University, Workshop in Political Theory and Policy Analysis. Draft Perspectives Paper for a special feature of PNAS on Beyond Panaceas, forthcoming.

Ostrom, Elinor, Burger, Joanna, Field, Christopher, Norgaard, Richard B., and Policansky, David (1999), “Revisiting the Commons: Local Lessons, Global Challenges,” 284(5412) Science, 278-282.

Ostrom, Elinor, Gardner, Roy and Walker, James (1994), Rules, Games, and CommonPool Resources, Ann Arbor: University of Michigan Press. 
Ostrom, Elinor and Walker, James (1991), “Communication in a Commons: Cooperation without External Enforcement,” in Thomas R. Palfrey (ed.), Laboratory Research in Political Economy, Ann Arbor: University of Michigan Press.

Ostrom, Elinor, Walker, James and Gardner, Roy (1992), “Covenants with and without a Sword: Self-Governance is Possible,” 86(2) American Political Science Review, $404-417$.

Pitman, G. (2002), Bridging Troubled Waters: Assessing the WB Water Resources Strategy, Washington, DC: WP-Operations Evaluation Department.

Pradhan, Prachanda (1989), Increasing Agricultural Production in Nepal: Role of LowCost Irrigation Development through Farmer Participation, Kathmandu, Nepal: International Irrigation Management Institute.

Pritchett, Lant and Woolcock, Michael (2004), "Solutions When The Solution is the Problem: Arraying the Disarray in Development,” 32(2) World Development, $191-212$.

Rapoport, Anatol (1966), Two-Person Game Theory: The Essential Ideas, Ann Arbor: University of Michigan Press.

Regmi, Ashok (2006), “The Role of Heterogeneity in Collective Action: A Look at the Intertie between Irrigation and Forests. Case Studies from Chitwan, Nepal,” Unpublished thesis, Indiana University.

Richerson, Peter J. and Boyd, Robert (2005), Not by Genes Alone: How Culture Transformed Human Evolution, Chicago: University of Chicago Press.

Satz, D. and Ferejohn, J. (1994), "Rational Choice and Social Theory,” 91(2) Journal of Philosophy, 71-87. 
Schlager, Edella and Ostrom, Elinor (1992), “Property-Rights Regimes and Natural Resources: A Conceptual Analysis,” 68(3) Land Economics, 249-262.

Schmid, A. Allan (2004), Conflict and Cooperation: Institutional and Behavioral Economics, Oxford: Blackwell.

Schmid, A. Allan and Thompson, P. (1999), “Against Mechanism: Methodology for an Evolutionary Economics,” 81(5) American Journal of Agricultural Economics, $1160-1165$.

Shepsle, Kenneth A. (1989), “Studying Institutions: Some Lessons from the Rational Choice Approach,” 1(2) Journal of Theoretical Politics, 131-149.

Shivakoti, Ganesh (1992), “Farmers’ Perceptions of System Effectiveness, Level of Participation and Equity in Farmer and Agency Managed Irrigation Systems in Nepal,” presented at the third annual conference of the International Association for the Study of Common Property, Washington, D.C., September 17-20.

Shivakoti, Ganesh and Ostrom, Elinor (2001), Improving Irrigation Governance and Management in Nepal, Oakland, CA: ICS Press.

Shivakoti, Ganesh, Varughese, George, Ostrom, Elinor, Shukla, Ashutosh and Thapa, Ganesh (eds) (1997), People and Participation in Sustainable Development: Understanding the Dynamics of Natural Resource Systems, Bloomington: Indiana University, Workshop in Political Theory and Policy Analysis; Rampur, Chitwan, Nepal: Tribhuvan University, Institute of Agriculture and Animal Science.

Shivakoti, Ganesh, Vermillion, Douglas, Lam, Wai-Fung, Ostrom, Elinor, Pradhan, Ujjwal and Yoder, Robert (eds) (2005), Asian Irrigation in Transition: Responding to Challenges, New Delhi, India: Sage. 
Shukla, A., Gajurel, K., Shivakoti, G., et al. (1993), Irrigation Resource Inventory of East Chitwan, Rampur, Chitwan, Nepal: Institute of Agriculture and Animal Science, Irrigation Management Systems Study Group.

Spiertz, H.L.J. (1991), “The Transformation of Traditional Law: A Tale of People’s Participation in Irrigation Management on Bali,” 20 Landscape and Urban Planning, 189-196.

Stake, Jeffrey (2004), “The Property Instinct,” Working Paper, Bloomington: Indiana University, School of Law.

Tang, Shui Yan (1992), Institutions and Collective Action: Self-Governance in Irrigation, San Francisco, CA: ICS Press.

Tsebelis, George (1990), Nested Games: Political Context, Political Institutions and Rationality, Berkeley: University of California Press.

Turral, H. (1995), "Recent Trends in Irrigation Management: Changing Directions for the Public Sector,” London: Overseas Development Institute, no. 5, September. Varughese, George and Ostrom, Elinor (2001), "The Contested Role of Heterogeneity in Collective Action: Some Evidence from Community Forestry in Nepal,” 29(5) World Development, 747-765.

von Wright, Georg Henrik (1951), “Deontic Logic,” 60 Mind, 1-15.

von Wright, Georg Henrik (1963), Norm and Action: A Logical Enquiry, London: Routledge \& Kegan Paul.

Walker, James, Gardner, Roy, Herr, Andrew and Ostrom, Elinor (2000), “Collective Choice in the Commons: Experimental Results on Proposed Allocation Rules and Votes,” 110(460) The Economic Journal, 212-234. 
WECS/IIMI (Water and Energy Commission Secretariat, Nepal, and International Irrigation Management Institute) (1990), Assistance to Farmer-Managed Irrigation Systems: Results, Lessons and Recommendations from an ActionResearch Project, Colombo, Sri Lanka: International Irrigation Management Institute.

Weissing, Franz and Ostrom, Elinor (1991), "Irrigation Institutions and the Games Irrigators Play: Rule Enforcement without Guards,” in Reinhard Selten (ed.), Game Equilibrium Models II: Methods, Morals, and Markets, Berlin: SpringerVerlag.

Weissing, Franz and Ostrom, Elinor (1993), “Irrigation Institutions and the Games Irrigators Play: Rule Enforcement on Government- and Farmer-Managed Systems,” in Fritz W. Scharpf (ed.), Games in Hierarchies and Networks: Analytical and Empirical Approaches to the Study of Governance Institutions, Frankfurt: Campus Verlag; Boulder, CO: Westview Press.

Wilson, James (2002), “Scientific Uncertainty, Complex Systems, and the Design of Common-Pool Institutions,” in National Research Council, Committee on the Human Dimensions of Global Change, Elinor Ostrom, Thomas Dietz, Nives Dolšak, Paul Stern, Susan Stonich, and Elke Weber (eds), The Drama of the Commons, Washington, DC: National Academy Press.

Winpenny, J.T. (1994), Managing Water as an Economic Resource, New York: Routledge.

Yoder, Robert D. (1991a), “Assistance to Farmer Managed Irrigation Systems: Experiences from WECS/IIMI/FORD Action Research Project in Indrawati 
Watershed Basin,” in N. Ansari and P. Pradhan (eds) Assistance to FarmerManaged Irrigation Systems: Experience from Nepal, Kathmandu, Nepal: Ministry of Water Resources, Department of Irrigation, Planning Design and Research Division.

Yoder, Robert D. (1991b), “Peer Training as a Way to Motivate Institutional Change in Farmer-Managed Irrigation Systems," in Proceedings of the Workshop on Democracy and Governance, Decentralization: Finance \& Management Project Report, Burlington, VT: Associates in Rural Development.

Yudelman, Montague (1985), The World Bank and Agricultural Development: An Insider’s View, World Resources paper no. 1, Washington, DC: World Resources Institution. 


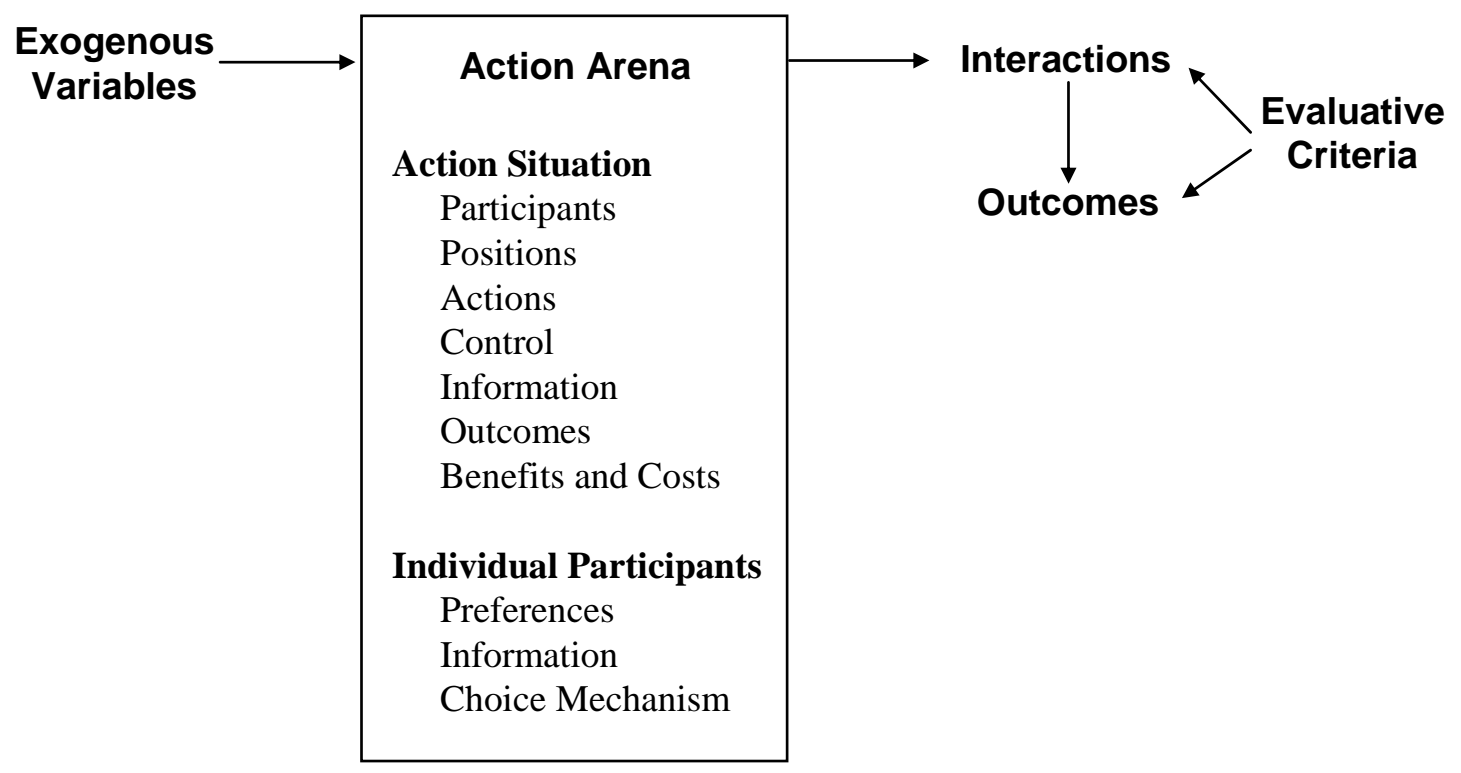

Figure 1. Unpacking the action arena. 


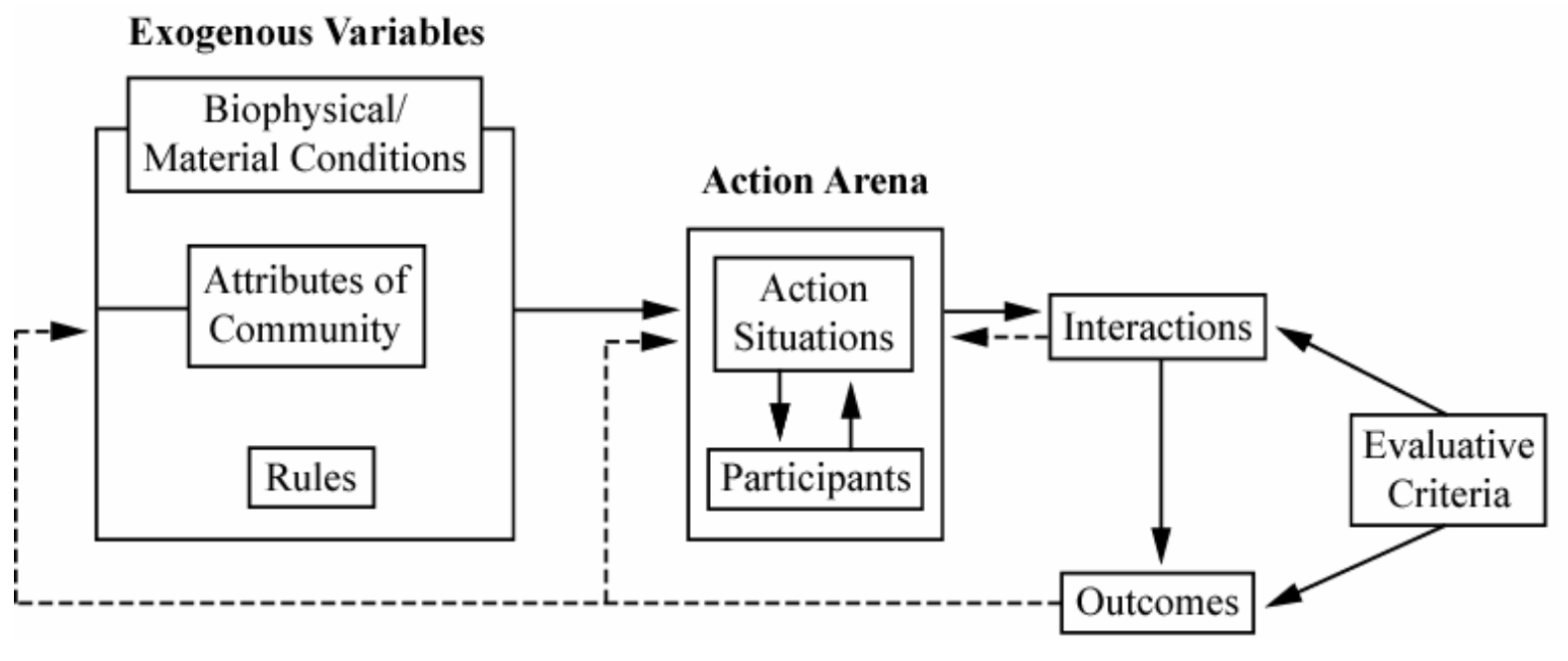

Figure 2. A framework for institutional analysis.

Source: Adapted from Ostrom, Gardner, and Walker (1994: 37). 
Table 1. Relationships between governance structure and physical condition of irrigation systems

\begin{tabular}{|c|c|c|c|c|c|}
\hline \multirow{2}{*}{\multicolumn{2}{|c|}{$\begin{array}{l}\text { Physical Condition } \\
\text { of Irrigation Systems }\end{array}$}} & \multicolumn{2}{|c|}{$\begin{array}{c}\text { Types of Governance } \\
\text { Structure }\end{array}$} & \multirow{4}{*}{$\begin{array}{c}\text { Chi- } \\
\text { Square } \\
\text { Value }\end{array}$} & \multirow{4}{*}{$\begin{array}{r}\text { Sig. } \\
\\
.00\end{array}$} \\
\hline & & \multirow{2}{*}{$\frac{\text { FMIS (\%) }}{18.2}$} & \multirow{2}{*}{$\frac{A M I S(\%)}{8.4}$} & & \\
\hline Overall & Excellent [37] & & & & \\
\hline & Moderately good [144] & 67.4 & 45.8 & & \\
\hline & Poor [48] & 14.4 & 45.8 & & \\
\hline \multirow{3}{*}{$\begin{array}{l}\text { Technical } \\
\text { efficiency }\end{array}$} & Highly efficient [58] & 28.9 & 12.5 & \multirow{2}{*}{27.30} & \multirow{2}{*}{.00} \\
\hline & Moderately efficient [137] & 62.8 & 50.0 & & \\
\hline & Inefficient [33] & 8.3 & 37.5 & & \\
\hline \multirow{3}{*}{$\begin{array}{l}\text { Economic } \\
\text { efficiency }\end{array}$} & Highly efficient [66] & 33.2 & 12.5 & \multirow{2}{*}{45.35} & \multirow{2}{*}{.00} \\
\hline & Moderately efficient [140] & 63.5 & 52.1 & & \\
\hline & Inefficient [23] & 3.3 & 35.4 & & \\
\hline
\end{tabular}

Source: Joshi et al. (2000: 78).

Note: Number of irrigation systems is in brackets. 
Table 2. Default conditions

Default position condition

Default entry condition

Default choice condition

Default aggregation condition

Default information condition

Default payoff condition

Default scope condition
No formal positions exist.

Anyone can enter.

Each player can take any physically possible action

Players act independently. Physical relationships present in the situation determine the aggregation of individual moves into outcomes.

Each player can communicate any information via any channel available to the player.

Any player can retain any outcome that the player can physically obtain and defend.

Each player can affect any state of world that is physically possible.

Source: Adapted from Ostrom (2005: 211). 
Table 3. Rules frequently identified in field studies of irrigation systems

\section{Boundary rules}

B1 Land: ownership or leasing of land within a specified location

B2 Shares: ownership or leasing of shares, transferable independent of land, to proportion of water flow

B3 Membership: belonging to a group required to receive water

\section{Position rules}

P1 Rotation: water users rotate into Monitor Position

P2 External monitor: hired guard from outside water user community

P3 Local monitor: hired guard from inside water user community

\section{Choice (Allocation) rules ${ }^{\mathrm{a}}$}

C1 Fixed percentage: the flow of water is divided into fixed proportions according to the land owned or some other formula

C2 Fixed time slot: each individual (or subcanal) assigned fixed time during which water may be withdrawn

C3 Fixed order: Farmers take turns to get water in the order in which they are located on a canal (or some other clear assignment)

\section{Information rules}

I1 Rule infraction publicity: announcement made in some public manner or rule breaking

I2 Measurement: Size of diversion weir publicly measured

I3 Reporting: Written minutes and financial reports available to all

\section{Aggregation rules}

A1 Neighbor agreement: both farmers must be present and agree at time slot change

A2 Community votes: time to change from one allocation rule to another

A3 Monitor decision: if farmers disagree, monitor has the final word

\section{Payoff rules}

Y1 Penalty: Farmers obliged to contribute money, labor, or some other resource for breaking a rule

Y2 Water tax: farmers pay an annual financial tax

Y3 Labor obligation: farmers contribute labor (according to an agreed formula) for regular maintenance and emergency repair

\section{Scope rules}

S1 Geographic domain: extent of land to which water may be applied

S2 Water use: limits on use of water obtained from a system

S3 Crops: limits on crops that may be grown using water from a system

\footnotetext{
${ }^{\mathbf{a}}$ We refer to these rules as choice rules, as they allow an individual to choose from zero water up to some upper limit. Thus, at the individual level, the allocation rule states what is permitted. At the system level, the rule requires that the specified type of allocation be enforced.
} 
Table 4. Rule configuration inventory

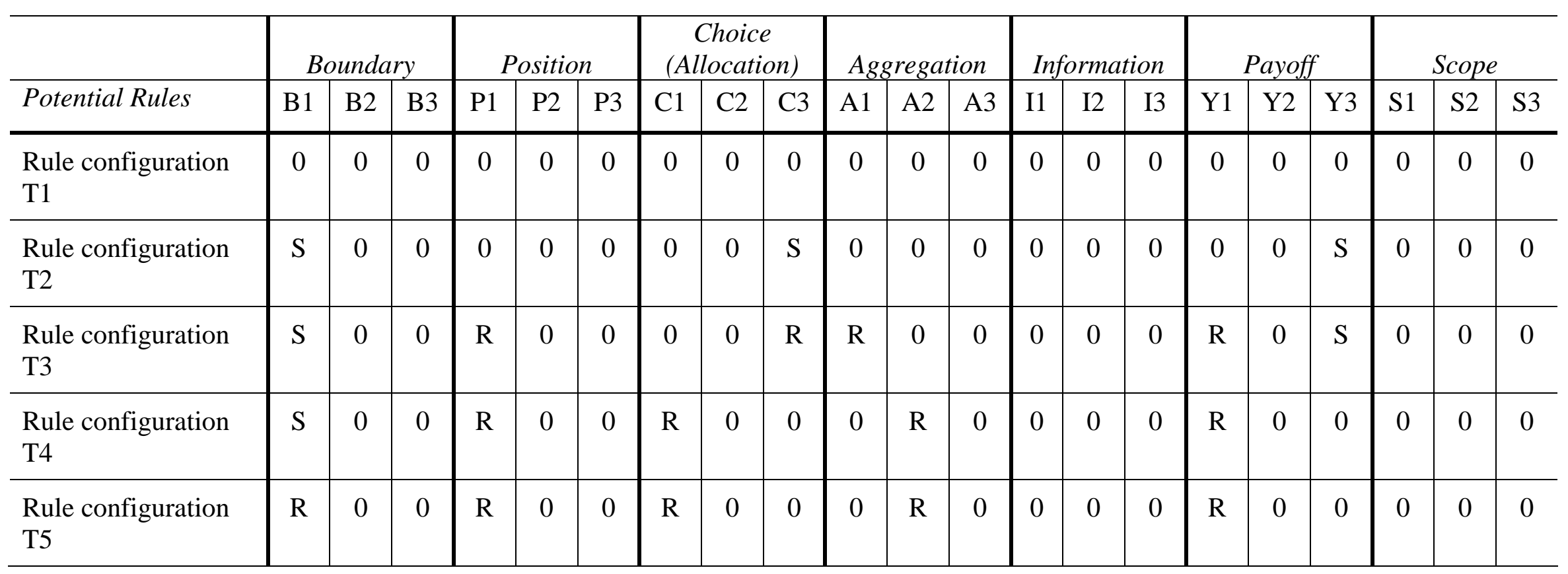

